\title{
Study of genetic diversity of Salmonella typhi using pulsed-field gel electrophoresis
}

\author{
Lucky Hartati Moehario, Retno Kadarsih Soemanto
}

\begin{abstract}
Abstrak
Telah dilakukan analisis kekerabatan genetik isolat Salmonella typhi yang di isolasi dari pasien demam tifoid sporadik yang dirawat inap di RS Persahabatan, Jakarta, pada semester I tahun 1998. Dari 25 isolat yang dicerna dengan Xbal ditemukan pola elektroforesis medan listrik berpulsasi (PFGE) yang bervariasi dan diidentifikasi 18 tipe PFGE. Analisis sidik gerombol menunjukkan bahwa kesemua isolat S. typhi berasal dari dua grup utama, dan pada tingkat kesamaan $>84 \%$ ditemukan 7 sidik gerombol. Penelitian ini menunjukan adanya keragaman genetik yang cukup tinggi pada berbagai isolat $S$. typhi, dan tampaknya berbagai isolat ini berasal usul bukan dari klon tunggal. (Med J Indones 2001; 10: 158-63)
\end{abstract}

\begin{abstract}
DNA genomes of Salmonella typhi (S.typhi), which were isolated from sporadic typhoid fever cases who were hospitalized in Persahabatan Hospital, Jakarta, during the $I^{\text {st }}$ semester of 1998, were examined for their genetic diversities. Pulsed-field gel electrophoresis (PFGE) of genomic DNA digested with Xbal was performed for 25 isolates. Electrophoresis patterns of most isolates varied and 18 PFGE types were identified. Cluster analysis showed that all isolates originated from two main groups; and at $\geq 84 \%$ level of similarity, 7 clusters were found. Thus, the results showed that genetic diversity of S. typhi was considerably high, and that $S$. typhi isolated from sporadic typhoid fever cases were derived from multiple clones. (Med J Indones 2001; 10: 158-63)
\end{abstract}

Keywords: typhoid fever, sporadic cases, Xbal, cluster analysis

Intensive studies of genetic djversity and molecular epidemiology of S.typhi, the etiologic agent of typhoid fever, have been carried out since early nineties. Quite a range of S.typhi isolates for various geographic regions representing sporadic cases, outbreaks, and environmental isolates have been analysed using pulse-field gel electrophoresis (PFGE). Those studies showed that there were significant diversity among S.typhi isolates, in which isolates originated from outbreak cases were more homogenous compared to sporadic isolates. Also, it is suggested that there was a movement of certain strains within Southeast Asia. ${ }^{1-5}$ In Indonesia, the bacteria causes a disease with a broader spectrum of serious complications, among others, typhoid hepatitis and typhoid pancreatitis. ${ }^{6}$ Further, mortality is frequently seen in Indonesia, while in other part of Asia, the disease manifestations

Department of Microbiology, Faculty of Medicine, University of Indonesia, Jakarta, Indonesia are milder. Previous study by Thong et al, $1996^{7}$ reported that certain PFGE types were associated with the ability to cause a fatal disease.

In the present study, we applied PFGE technique to analyse large fragments of chromosomal DNA to enable us to determine the genetic relationship among S.typhi isolates. The result obtained can be used for epidemiology purposes, since it can contribute in the construction of highly accurate $S$. typhi genetic map for the whole region in Indonesia.

\section{METHODS}

All procedures below were performed in the Laboratory of the Department of Microbiology, Faculty of Medicine, University of Indonesia, during 19992000, except for the electrophoresis using CHEF DR III electrophoresis unit, which were conducted in Microbes and Genetic Engineering Division, R\&D Centre for Biotechnology, Indonesia Institute of Science, Cibinong. 


\section{Bacteria}

Twenty five S.typhi isolates were randomly chosen from the collections of Dr. RHH Nelwan, Department of Internal Medicine, Faculty of Medicine, University of Indonesia, Jakarta. The isolates were originated from sporadic cases of typhoid fever, which were hospitalized in the first semester of 1998, in Persahabatan Hospital, Jakarta. All isolates were tested for antibiotic susceptibility by standard disk diffusion procedures. No resistance was observed to amoxicillin (AML), amoxicillin clavunamic acid (AMC), chloramphenicol (C), trimethoprim sulphamethoxazole (SXT), ciproxin (CIP), ofloxacin (OFP), lefofloxacin (LFX), streptomycin (S), tetracyclin (T), cefdinir (CFN), cefprozil (CPR), ceftriaxone (CRO), cefepime (FEP), or amikacin (AN).

\section{PFGE and genome analysis}

Chromosomal DNA was prepared as described by Suwanto and Kaplan, 1989, and Thong et al, 1994. ${ }^{5}$ In brief, overnight cultures were centrifuged at $4000 \mathrm{~g}$ for $5 \mathrm{~min}$. at $4^{\circ} \mathrm{C}$ and washed twice in $1 \mathrm{ml}$ buffer containing $10 \mathrm{mM}$ Tris $\mathrm{HCl} \mathrm{pH} 7.5$ and $1 \mathrm{M} \mathrm{NaCl}$. Pellets were resuspended in the same buffer and mixed with $1 \%$ low melting agarose in $1 \mathrm{x}$ TE buffer (10 mM Tris $\mathrm{HCl} \mathrm{pH} 8.0$ and 1 mM EDTA pH 8.0). The agarose blocks were then subjected to lysing solution containing $1 \mathrm{mg} / \mathrm{ml}$ lysozyme and incubated at $37^{\circ} \mathrm{C}$ overnight. The following day, the lysing solution were replaced with solution containing 100 $\mu \mathrm{g} / \mathrm{ml}$ proteinase $\mathrm{K}, 0.5 \mathrm{M}$ EDTA $\mathrm{pH} 8.0$ and $10 \%$ sarcosyl followed by incubation at $55^{\circ} \mathrm{C}$ for 48 hours. The $X b a I$ restriction enzyme (Promega, Madison, WI, USA) was used, and digestion was performed according to the manufacturer. The digested chromosomal DNA were then electrophoresed using CHEF DR III electrophoresis unit (Biorad Laboratories, Hercules, CA, USA) at $14^{\circ} \mathrm{C}$ with a $120^{\circ}$ switch angle, and a running time of 20 hours with a linear ramp of switching time from $5-50 \mathrm{sec}$, at $6 \mathrm{Volt} / \mathrm{cm}^{2}$. Rhodobacter sphaeroides 2.4.1 digested with $\mathrm{Asel}^{8}$ was generously provided by DR. Antonius Súwanto from Inter University Center for Biotechnology, Institute of Agriculture Bogor, Bogor, Indonesia, and used as molecular marker. Gels were stained with ethidium bromide, destained and photographed under UV light.
Interpretation of PFGE gel patterns was carried out as described by Bannerman et al, 1995, ${ }^{9}$ and Zadoks et al, 2000, ${ }^{10}$ and assigned for arbitrary pattern types, and compared by calculating Dice similarity coefficient $(F$, proportion of share fragments between two isolates). $F$ value of 1.0 indicates identical pattern, and $F$ value of 0 suggests complete dissimilarity. ${ }^{11,12}$ Electrophoretic patterns were analysed for relatedness using a computer program Numerical Taxonomy and Multivariate Analysis (NTSYS-pc) version $1.80 .^{13}$ Dendograms were constructed by using Dice coefficient, and clustering by using unweighted pair group arithmetic means method (UPGMA).

\section{RESULTS}

A total of 25 human isolates of S.typhi were analysed following digestion with XbaI (5'-TCTAGA-3') restriction endonuclease and electrophoresis using PFGE. Digested chromosomal DNAs produced 10 to 20 fragments with molecular weight ranging from 30 $\mathrm{kb}$ to $650 \mathrm{~kb}$ and showed various PFGE patterns as shown in Fig. 1A and 1B. Close examination to these bands showed that DNA fragments with molecular weight between $31 \mathrm{~kb}$ to $97 \mathrm{~kb}$, and around $340 \mathrm{~kb}$ were relatively conserved in most of the isolates. However, bands between $97 \mathrm{~kb}$ to $340 \mathrm{~kb}$, and above $340 \mathrm{~kb}$ were more various. Analysis of genetic relatedness among S.typhi isolates showed a quite significant diversity among them as represented by their $\mathrm{F}$ values (Fig. 2A), and the presence of 18 different PFGE types (pulsotypes) designated X1 to $\mathrm{X} 18$, and 4 subtypes as follows: X1.1, X1.2, X2.1 and $\mathrm{X} 2.2$ (see Table 1). Despite the divergence of $\mathrm{F}$ values, certain pulsotypes were either identical or very similar, in that they were different in only 1 or 2 bands. There were 5 S.typhi isolates (isolate no. 3, 23, 43,44 and 52) with $\mathrm{F}$ value between $0.923-1.000$, and therefore they were grouped together in PFGE cluster II. Three of these isolates, i.e. isolate no. 23, 43 and 52 were identical with $\mathrm{F}$ value 1.000. Moreover, 4 other isolates (isolate no. 46, 48, 55 and 56) showed high degree of similarity with $\mathrm{F}$ between $0.941-0.971$, and were grouped in cluster I (see Fig 2A and 2B). 
(A)

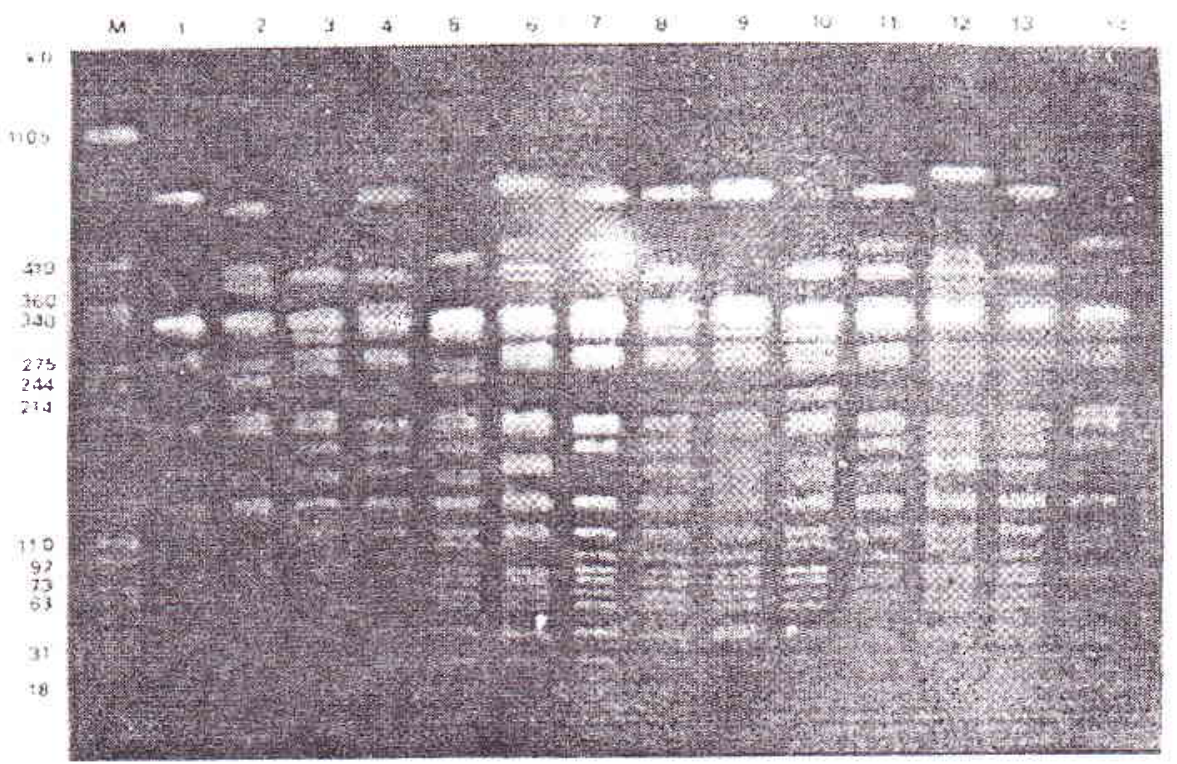

(B)

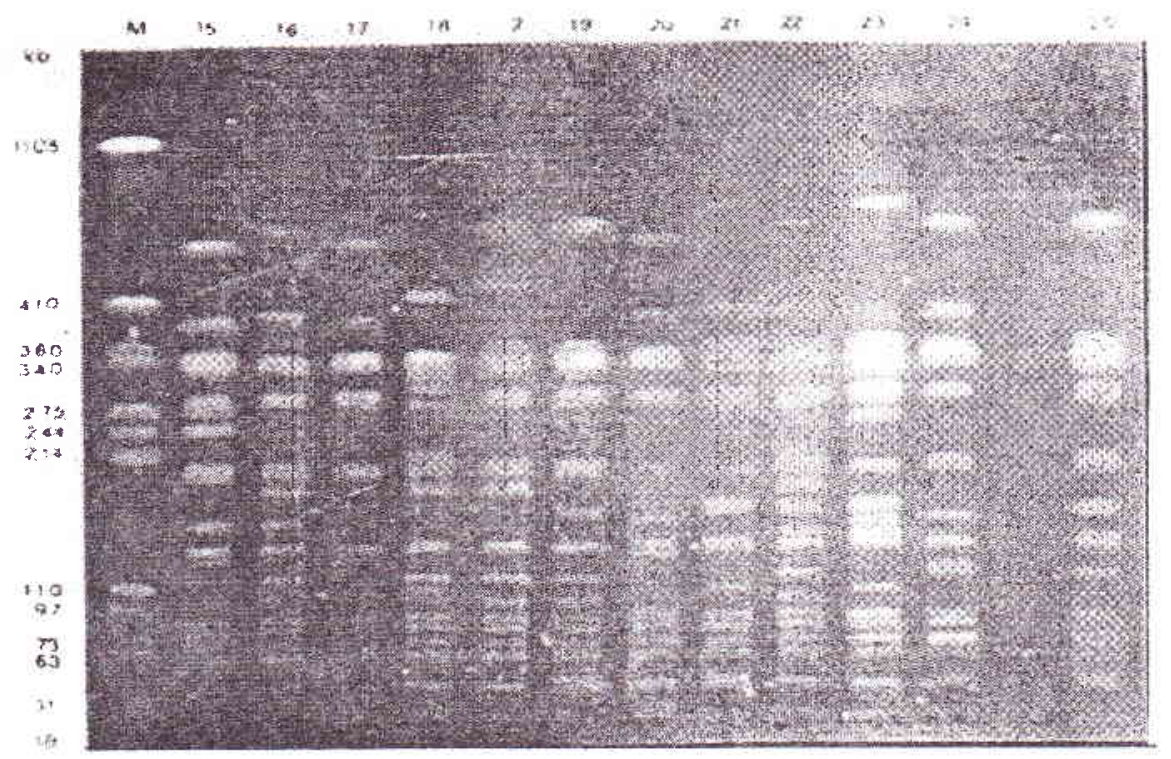

Figure 1. Agarose gel showing Xbal digested DNA of S. typhi isolates originated from hospitalised, sporadic typhoid fever patients. (A) Lanes 1-14 represent restriction enzyme digested DNA patterns of isolate number: $55,29,39,23,49,18,45,43,46,32,44,33,52$, and 47. (B) Lanes 15-25 represent isolate number: $63,54,50,51,45,56,58,2,3,53,59$, and 48. Lane M: PFGE marker (Rhodobacter sphaeroides 2.4.1. digested with AseI) in kb pairs. 
(A).

$55 \quad 1,000$

$29 \quad 0.5141 .000$

$39 \quad 0,6670.70 .31 .000$

$23 \quad 0.91405000 .7571000$

$49 \quad 0.6290 .7220 .86506671 .000$

180.7650 .5710 .77808000 .6861 .000

$45 \quad 0.8820 .5140 .7220 .9140 .6860 .7651 .000$

$43 \quad 0.9140 .5000 .757 \mathbf{1 . 0 0 0} 06670.8000 .9141 .000$

$46 \quad 0.9710 .5560 .7030 .88906670 .8000 .8570 .8891 .000$

320.722064908950 .75707570 .83306670 .7570 .7571 .000

$44 \quad 0.88904860 .7370 .9730 .6490 .83309440 .9730 .8650 .7371 .000$

$33 \quad 0.7570 .5260 .8210 .8420 .7890 .8650 .7570 .8420 .7890 .8210 .8211 .000$

$520.9140 .5000 .7571 .0000 .6670 .8000914 \mathbf{1 . 0 0 0} 08890.7570 .9730 .842 \mathrm{i} .000$

$47 \quad 0.7220 .6490 .8950 .7570 .8110 .7780 .8330 .7570 .7570 .7890 .7890 .7690 .7571 .000$

630.6860 .7780 .7570 .6670 .7220 .74306290 .6670 .7220 .7570 .64906840 .6670 .6491 .000

$54 \quad 0.78805290 .8000 .8820 .7060 .72708480 .8820 .7650 .7430 .8570 .7780 .8820 .7430 .7061,000$

$50 \quad 0.66707650 .7470 .6470 .5880727060606470 .7060 .7430 .6290 .6670 .6470 .6860 .8820 .6251 .000$

$51 \quad 0.6670 .5880 .85707060 .8820 .7270 .7270 .70607060 .74306860 .8330 .7060 .8570 .6470 .6880 .6251 .000$

$56 \quad 0.9410 .5710 .6670 .8570 .6860 .7650 .8240 .8570 .9710 .7220 .8330 .7570 .8570 .7220 .6860 .7270 .6670 .6671 .000$

$58 \quad 0.60608240 .800064707060 .7270 .6060 .6470647080006290 .6670 .6470 .6860 .8820 .6880 .8750 .6250 .6061 .000$

20.8000 .556070 .30 .7780 .6110 .85706860 .7780 .8330 .7570 .7570 .8420 .7780 .6490 .7780 .7060 .7650 .6470 .8000 .7061000

$3 \quad 0.8650 .5260 .7690 .9470,6840.8110 .8650 .9470 .8950 .7690 .9230 .8500 .9470 .7690 .6840 .8330 .6670 .7220 .8650 .6670 .7891 .000$

$5.30 .684061506500 .7180 .6150 .7890 .6 .320 .7180 .7180 .7000 .7000 .7800 .7 \mathrm{~J} 80.6000 .7180 .6490 .6490 .5950 .6840 .7030 .8720 .7801 .000$

59 0.7650 .62908890 .8000 .7430 .7650 .765080007430 .8890 .7780 .7570 .8000 .8330 .743084807270 .7270 .7060 .7880 .6860 .7570 .6321 .000

480.9410 .5710 .7220 .9140 .6860 .8240 .8820 .9140 .9710 .7780 .88908110 .9140 .7780 .6860 .7880 .6670 .7270 .9410 .6670 .8000 .9190 .7370 .7651 .000

Figure 2. (A). Matrix of $F$ values of $25 S$. typhi isolates. The far left ordinate represents the isolate's number.

(B).

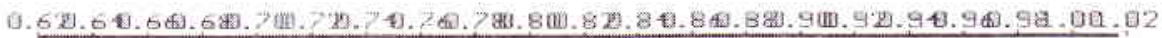

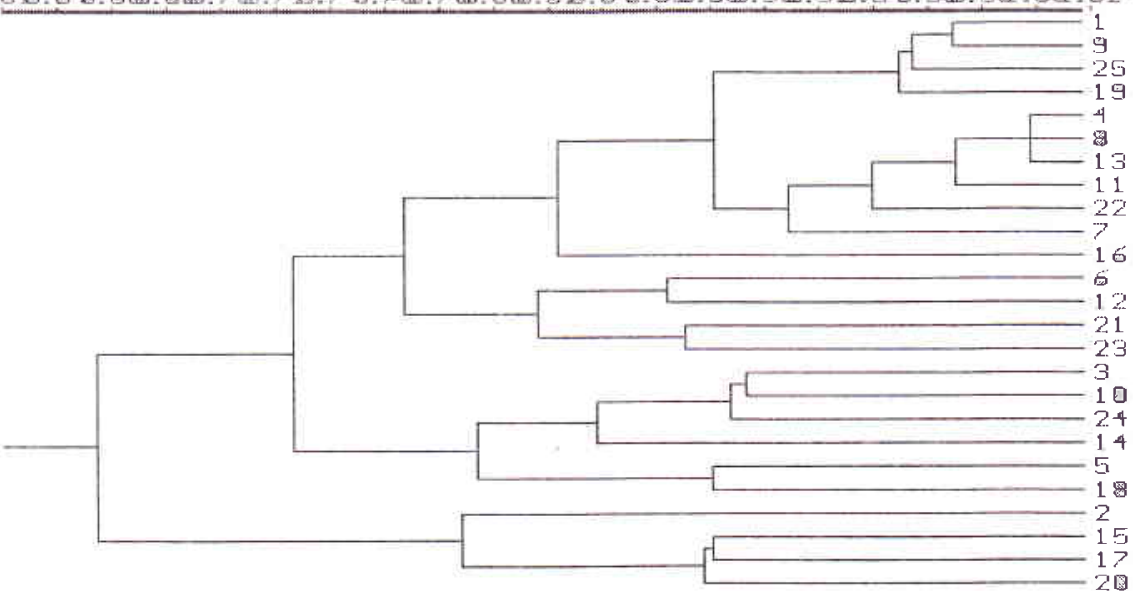

Isolates No.

Figure 2. (B) Dendogram showing the clusters derived from the 25 S. typhi isolates, which was constructed by the NTSYS-pc version 1.8 program on the basis of $F$ values and the unweighted pair group arithmetic means methods (UPGMA). Scale indicates level of genetic relatedness between collection of isolates. 


\section{REFERENCES}

1. Wain J, Hien TT, Connerton P, Ali T, Parry CM, Chinh NTT, et al. Molecular typing of multiple antibiotic resistant Salmonella enterica serovar typhi from Vietnam: Application to acute and relapse cases of typhoid fever. J Clin Microbiol 1999; 37: 2466-72.

2. Thong KL, Nair S, Subramaniam G, Puthucheary S, Yassin R, Cheong YM, et al. Genetic dynamics and molecular epidemiology of Salmonella typhi. Med J Indones, 1998; 7 Suppl 1: 147-50.

3. Koay AS, Jegathesan M, Rohani MY, Cheong YM. Pulsed-field gel electrophoresis as an epidemiologic tool in the investigation of laboratory acquired Salmonella typhi infection. Southeast Asia J Trop Med Public Health 1997; 28: 82-4.

4. Thong KL, Puthucheary S, Yassin RM, Sudarmono P, Padmidewi M, Soewandojo E, et al. Analysis of Salmonella typhi isolates from Southeast Asia by pulsed-field gel electrophoresis. J Clin Microbiol 1995; 33: 1938-41.

5. Thong KL, Cheong YM, Puthucheary S, Koh CL, Pang T. Epidemiologic analysis of sporadic Salmonella typhi isolates and those from outbreaks by pulsed-field gel electrophoresis. J Clin Microbiol 1994; 32: 1135-41.

6. Nelwan RHH. Changing pattern of typhoid fever complications in Indonesia. Med J Indon, 1998; 7 Suppl 1: 105.

7. Thong KL, Passey M, Clegg A, Combs BG, Yassin RM, Pang T. Molecular analysis of isolates of Salmonella typhi obtained from patients with fatal and nonfatal typhoid fever. J Clin Microbiol 1996; 34: 1029-33.

8. Suwanto A, Kaplan S. Physical and genetic mapping of the Rhodobacter sphaeroides 2.4.1. genome: Genome size, fragment identification, and gene localization. J Bact 1989; 171(11): 5840-9.

9. Bannerman TL, Hancock GA, Tenover FC, Miller JM. Pulsed-field gel electrophoresis as a replacement for bacteriophage typing of Staphylococcus aureus. J Clin Microbiol 1995; 33; 551-5.

10. Zadoks $R$, Leeuwen W, Barkema H, Sampimon O, Verbrugh H, Schukken YH, et al. Application of pulsedfield gel electrophoresis and binary typing as tools in veterinary clinical microbiology and molecular epidemiology analysis of bovine and human Staphylococcus aureus isolates. J Clin Microbiol 2000; 38: 1931-9.

11. Romling U, Grothues D, Heuer T, Tummler B. Physical genome analysis of bacteria. Electrophoresis 1992; 13: 626-31.

12. El-Adhami W, Roberts L, Vickery A, Inglis B, Gibbs A, Stewart P. Epidemiological analysis of a methicillinresistant Staphylococcus aureus outbreak using restriction length polymorphisms of genomic DNA. J Gen Microbiol 1991; 137: 2713-20.

13. Rohlf FJ. NTSYS-pc: Numerical Taxonomy and Multivariate Analysis System Version 1.80. New York: Exeter Software; 1993.

14. Prevost G, Jaulhac B, Piemont Y. DNA fingerprinting by pulsed-field gel electrophoresis is more effective than ribotyping in distinguishing among methicillin-resistant Staphylococcus aureus isolates. J Clin Microbiol 1992; 39: 967-73.

15. Lefevre JC, Faucon G, Sicard AM, Gasc M. DNA fingerprinting of Streptococcus pneumoniae strains by pulsed-field gel electrophoresis. J Clin Microbiol 1993; 31: 2724-8.

16. Anderson DJ. Kuhns JS, Vasil ML, Gerding DN, Janoff EN. DNA fingerprinting by pulsed-field gel electrophoresis and ribotyping to distinguish Pseudomonas cepacia isolates from a nosocomial outbreak. J Clin Microbiol 1991; 29: 648-9.

17. Hector JSR, Pang YJ, Mazurek GH, Zhang YS, Brown BA, Wallace RJ. Large restriction fragment patterns of genomic Mycobacterium fortuitum DNA as strain-specific markers and their use in epidemiologic investigation of four nosocomial outbreaks. J Clin Microbiol 1992; 30: 1250-5.

18. Chee CS, Noordin N, Ibrahim L. Epidemiology and control of typhoid fever in Malaysia. In: Pang T, Koh CL, Puthucheary SD, editors. Typhoid fever: Strategies for the 90's. Singapore: World Scientific Publishing; 1992.p.310.

19. Liu SL, Sanderson KE. Genomic cleavage map of Salmonella typhi. J Bacteriol 1995; 177: 5099-107. 